JOURNAL OF SECURITY AND SUSTAINABILITY ISSUES

ISSN 2029-7017 print/ISSN 2029-7025 online

2019 June Volume 8 Number 4

http://doi.org/10.9770/jssi.2019.8.4(24)

Scopus

\title{
INFLUENCE OF IPO ON MACROECONOMIC SECURITY OF COUNTRIES
}

\author{
Marek Garbowski ${ }^{1}$, Daria Mironova ${ }^{2}$, Iryna Perevozova ${ }^{3}$, Nila Khrushch ${ }^{4}$, Iurii Gudz ${ }^{5}$ \\ ${ }^{1}$ University of Warmia and Mazury in Olsztyn, 10-719 Olsztyn, Poland \\ ${ }_{2}^{2}$ Institute of Service and Business (branch) of Don State Technical University, Shakhty \\ ${ }^{3 *}$ Ivano-Frankivsk National Technical University of Oil and Gas, 15 Karpatska Street, Ivano-Frankivsk, Ukraine \\ ${ }^{4}$ Khmelnytskyi National University, 11 Instytutska, Khmelnytskyi, 29016, Ukraine \\ ${ }^{5}$ Donetsk National University of Economics and Trade named after Mykhailo Tugan-Baranovsky, \\ vul.Ostrovskyi, 16, Kryvyi Rih, Ukraine \\ E-mail: ${ }^{*}$ lubanes@gmail.com
}

Received 17 January 2019; accepted 26 April 2019; published 30 June 2019

\begin{abstract}
In the scientific work the influence of the factor of primary public offer of securities on the macroeconomic security of the country is considered. A comparative description of the main financing attraction tools is presented. The advantages and disadvantages of using IPO in countries with developed stock market and developing countries are explored. The analysis of the development of European and Ukrainian markets of IPOs in terms of impact on general macroeconomic security has been carried out. The relationship between macroeconomic stability and economic development of the IPO is established.
\end{abstract}

Key words: IPO stock market; stock exchange; macroeconomic security; correlation-regression analysis; investment; state of the national economy

Reference to this paper should be made as follows: Garbowski, M.; Mironova, D.; Perevozova, I.; Khrushch, N.; Gudz, I. 2019. Influence of IPO on macroeconomic security of countries, Journal of Security and Sustainability Issues 8(4): 841-853.

http://doi.org/10.9770/jssi.2019.8.4(24)

JEL Classifications: G11, O47

\section{Introduction}

The pattern of the global economy development determines the need for companies to invest in the development and stabilization of economic security, shaping the demand for the international capital market. One of the modern methods of attracting external financing is the primary public offering or primary public offering (IPO). The total amount of funds attracted within the framework of IPO deals on the world market annually reaches hundreds of billions of US dollars and becomes comparable to the national GDP of many countries, shaping their macroeconomic security.

During the current stage of development of the global IPO market (1997-2017), more than 25 thousand companies succeeded in attracting money through IPO in the world. Under the influence of globalization, which leads to the simplification of the transboundary movement of capital, the global financial centers focus on IPO markets, which changes the supply-side balance on regional and national equity markets, especially in the equity markets of developing countries (Korauš, A.; Gombár, M.; Kelemen, P.; Backa, S., 2019; Karpenko, L.; Serbov, M.; Kwilinski, A.; Makedon, V. \& Drobyazko, S., 2018; Mokhova, N.; Zinecker, M.; Meluzín, T. 2018; Masood, O.; Tvaronavičienè, M.; Javaria, K. 2019). 
The intensity of IPO implementation, their efficiency (dynamics of securities quotations) and success (volume of attracted capital), as well as activity in the IPO markets are some of the parameters that allow to assess the state of the national macroeconomic security, as well as to determine the mood of investors and predict their behavior. IPO process participants should take into account the manifestation of global, regional and national patterns and trends in the market of primary public offerings. The global IPO market is influenced by various factors, including macroeconomic, political and geopolitical. One of the main objectives of the IPO is to maximize the capital attracted, while the high quality execution of technical preparation for an IPO does not guarantee a successful, efficient and profitable placement. Macroeconomic indicators, the state of the capital market, the current phase of the economic cycle, the choice of the site and the time for the placement, as well as internal indicators of the issuing company and many other factors can have a decisive influence both on the effectiveness of the IPO and on the level of macroeconomic security of the country.

Understanding the essence of the factors that influence the process of implementing an IPO both at the national and global markets will allow to increase the level of efficiency of placements and provide proper security (Drobyazko S., 2018a, b; Tvaronavičienè, M. 2018; Shuyan, L.; Fabuš, M., 2019).

The theoretical basis for research on the market for primary public placement was the work of leading scholars and economists, namely (Bruton et al. 2009; Elston, and Yang, 2010; Engelen and Essen 2010; Hoechle and Schmid 2007; Lin and Chuang, 2011; Johnston, and Madura, 2009). The fundamental basis of this study was also the work of studying the world and regional capital markets (Afza et al. 2013; Boulton et al. 2009; Makedon and Korneyev 2014; Mangena and Pike 2005; Welch and Ritter; 2002; Štiglic, D., 2017; Masood et al., 2017; Ashraf et al., 2019).

The basic work on the theme of foreign authors of interest to us, is devoted, mainly, to studying the issues of determining the IPO time and stock market analysis. The markets of the developing countries were less studied, and the IPO market in Ukraine was studied by single researchers. In modern scientific literature and scientific periodicals insufficient attention is paid to the influence of the quality of IPO on the macroeconomic security of the country, this aspect and determines the scientific expediency and relevance of this study.

\section{The main tools for attracting funding}

Initial public offering of IPO shares is considered one of the most effective and fastest investment attraction tools, which is gaining popularity among Ukrainian companies as well. Participants of investment activity, in accordance with the current legislation of Ukraine, citizens and legal entities of Ukraine and other countries that can ensure the implementation of investments as executors of orders or on the basis of an investor's order may be citizens. Investment activity of companies is related to its need to finance its activities by using certain objects of ownership of a legal entity. For companies, a perspective way of attracting additional capital may be the placement of shares through the initial public offering of shares on the stock exchange (IPO). In this way, the company deducts a part of its ownership (or even its entirety) into open-label free-selling (Bochner et al. 2016; Masood, O.; Tvaronavičienè, M.; Javaria, K., 2019).

In Table 1 the comparative characteristics of the main instruments for attracting financing by companies in the international investment market are shown.

Comparing the above-mentioned ways of raising capital, it can be concluded that for companies it is easier and more affordable for companies to sell a stake in a company through participation in $\mathrm{M} \& \mathrm{~A}$ transactions (mergers and acquisitions). 
Table 1. Comparative characteristics of the main capital attraction tools

\begin{tabular}{|c|c|c|}
\hline $\begin{array}{c}\text { Tool } \\
\text { for attracting } \\
\text { capital } \\
\end{array}$ & IPO & M\&A (mergers and acquisitions) \\
\hline Advantages & $\begin{array}{l}\text { - maintaining the control over the company; } \\
\text { - obtaining a market valuation of the company; } \\
\text { - improvement of financial reputation of the company, which } \\
\text { enables cheaper debt capital attraction in the future; } \\
\text { - enhancing the recognition and image of the company, which } \\
\text { will contribute expanding sales markets and attracting the best } \\
\text { human resources }\end{array}$ & $\begin{array}{l}\text {-there are no restrictions on the organizational and } \\
\text { legal form of companies;; } \\
\text {-lack of requirements for further public disclosure; } \\
\text {-the possibility of obtaining a price above market; } \\
\text { - potential source of further funding; } \\
\text {-there is no need to bring the company into } \\
\text { compliance with the criteria of stock exchanges; } \\
\text {-relatively low transaction costs }\end{array}$ \\
\hline Disadvantages & $\begin{array}{l}\text { - restrictions on the legal form of companies; } \\
\text {-the need to bring the company into compliance with certain } \\
\text { criteria; } \\
\text {-Permanent requirements for disclosure of information, } \\
\text { interaction with investors; } \\
\text {-the effect of the situation on the financial } \\
\text { markets in the value of shares of the company; } \\
\text { - relatively high costs }\end{array}$ & $\begin{array}{l}\text { - restrictions on strategic decisions admissions; } \\
\text {-absence of a market valuation of a company }\end{array}$ \\
\hline
\end{tabular}

Source: Initial Public Offerings, Pricing Differences; Available on the Internet:

https://www.sec.gov/fast-answers/answersipopricinghtm.html; Investor Alert: Pre-IPO Investment Scams (Updated). Available on the Internet: https://www.investor.gov/additional-resources/news-alerts/alerts-bulletins/investor-alert-pre-ipo-investment-scams-updated; Ritter, 2011

In spite of this, public offering of shares provides many benefits, which may be of great significance for a company that is in the stage of its active development. Consequently, it can not be clearly stated that this or that capital attraction tool is the best. The right choice depends on the personal goals of the company's owners, the strategic goals of the company, the company's willingness to become public or to a certain investor, as well as the market environment. In addition, IPOs and M \& As can be complementary tools that are appropriate at different stages of company development and towards achieving different strategic goals and achieving security of economic development. (Consulting firm (Poland).

The interest in conducting IPOs in recent times is due to the fact that this is the most effective way to simultaneously attract the necessary amount of additional financial resources, attract strategic investors and maintain state control over its strategic assets.

For countries with a developed stock market, an IPO is considered to be one of the most effective instruments for raising capital, due to the following benefits that the company gains due to its holding (Gajewski, and Gresse, 2006; Loughran, and Ritter, 2004):

- definition of market value of the company;

- ensuring the growth of the company's value;

- improvement of financial condition;

- increase in liquidity of shares;

- access to the stock market;

- formation of economic security;

- attracting and retaining key personnel;

- absence of debt obligations;

- attracting financial resources in the future on favorable terms;

- ensuring macroeconomic security.

The main disadvantages of the IPO can be (Poberezhets, et. al. 2018):

- changing the level of corporate rights and control;

- significant expenses;

- duration of implementation; 
- publicity of the company (disclosure);

- irreversibility of the process.

\section{Trends in the development of the European IPO market}

The European IPO market remains one of the leading markets in the world and significantly increases the volume of placed shares. Despite the fact that the value of the European IPO in 2016 amounted to 27.9 billion euros, a decrease of 51\% compared to 2015, in 2017 a stable economic and political situation in Europe contributed to the growth of the market (EY Global, 2017).

The reasons for the reduction of the European IPO market in 2016 were, first of all, political uncertainty and slowdown of the growth rate of the economy. Political uncertainty, falling oil and commodity prices, as well as concerns over economic slowdown in China, prevented European markets from launching an IPO in 2016. In 2015, there were only five IPOs in the media sector (IPO, which increased more than 1 billion euros).

At the same time, on some stock exchanges there was an increase in the IPO. So 2016 will be remembered as a great year for Nasdaq Nordic, as revenues on this stock exchange have grown by $33 \%$, which has led to growing trends in Europe. Nasdaq Nordic accounted for 28\% of all European IPOs in 2016, compared with 10\% in 2015, with the second and third largest IPO in Europe, Dong A / S and Nets. Conversely, the London Stock Exchange accounts for $24 \%$ of its IPO revenues in 2016 compared with $29 \%$ in 2015.

The cost of IPOs for companies amounted to EUR 43.9 billion in 2017, up 57\% from EUR 27.9 billion compared with 2016. Overall, in 2017, there were 348 IPOs across Europe, compared with 268 IPOs in 2016. An average price of $€ 195$ million in 2017 will increase by $6 \%$ to $€ 184$ million in 2016.

The value of the European IPO in 2017 amounted to EUR 43.9 billion, an increase of $57 \%$ compared with 2016, when the volume of IPO increased by $30 \%$. Improving the economic environment throughout the EU has provided an ideal environment for the prosperity of the IPO market, as a number of candidates who postponed their plans to hold an IPO in 2016, entered the list in 2017. Geopolitical uncertainty remains linked to Brexit's ongoing talks, however, markets confirm to be stable when volatility remains low and indicators reach record highs.

London returned to its first place both in value and volume, rising by 12.5 billion euros, an increase of $86 \%$ by 2016, mainly due to an increase in the number of investment instruments and an increase in cross-border IPO operations (IPO Watch Europe, 2017). The London and Irish stock exchanges also jointly organized the largest European IPO in 2017, Allied Irish Banks plc. Borsa Italiana is also part of the London Stock Exchange, which became the second most active exchange in terms of raising the value of $€ 5.2$ billion after the Pirelli mega-IPO (IPO Watch Europe, 2018).

In Figure 1 the dynamics of the volume of the European IPO (IPO) market in 2007-2017 is shown. With regard to the European market for IPO, during the post-crisis period, the lowest stock exchanges in Europe were the volume of attracted capital in 2008, 2009, 2012: 14; 7.1 and 11.3 billion euro respectively (IPO Watch Europe, 2018). 


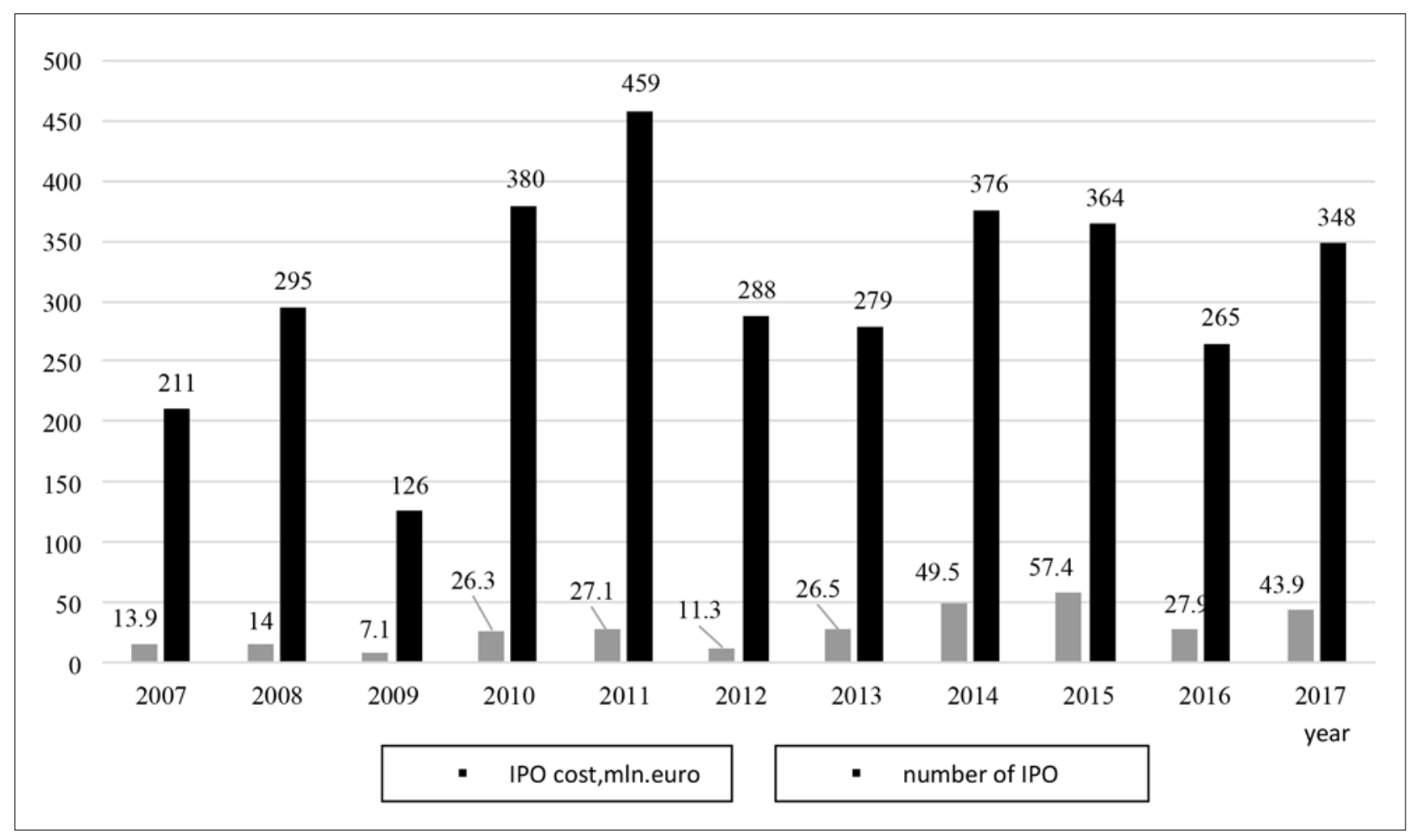

Figure 1. Dynamics of the European IPO (IPO) market volume in 2007-2017

Source: Prepared by the authors from statistical processing results year

In Table 2 the dynamics of IPO production on European stock exchanges in 2015-2017 is shown.

Table 2. Dynamics of issuance of IPOs on European stock exchanges in 2015-2017

\begin{tabular}{|c|c|c|c|c|c|c|c|}
\hline Indicator & & Years & & Absolute & viation, $+/-$ & Rate of & rease, $\%$ \\
\hline Exchange value of the offer, million euros & 2015 & 2016 & 2017 & $2016-2015$ & $2017-2016$ & $2016 / 2015$ & $2017 / 2016$ \\
\hline London Group of Stock Exchanges & 16370 & 8043 & 17634 & -8327 & 9591 & $-50,87$ & 119,25 \\
\hline London Stock Exchange & - & 67 & 12472 & 67 & 12405 & - & 18514,93 \\
\hline Borsa Italiana & - & 1343 & 5162 & 1343 & 3819 & - & 284,36 \\
\hline Nasdaq Nordic & 5905 & 7861 & 3996 & 1956 & -3865 & 33,12 & $-49,17$ \\
\hline Nasdaq Stockholm & 5216 & 2222 & 2326 & -2994 & 104 & $-57,40$ & 4,68 \\
\hline Nasdaq Helsinki & 409 & 676 & 1475 & 267 & 799 & 65,28 & 118,20 \\
\hline Nasdaq Copenhagen & 168 & 4891 & 185 & 4723 & -4706 & 2811,31 & $-96,22$ \\
\hline Nasdaq Tallinn & - & 14 & 4 & 14 & -10 & - & $-71,43$ \\
\hline Nasdaq Riga & - & - & 3 & - & 3 & - & - \\
\hline Nasdaq Iceland & 112 & 58 & - & -54 & - & $-48,21$ & - \\
\hline Nasdaq Vilnius & & - & 3 & - & - & - & - \\
\hline Nasdaq Copenhagen & 168 & & & -168 & 0 & $-100,00$ & - \\
\hline Six Swiss exchanges & 2039 & 733 & 3853 & -1306 & 3120 & $-64,05$ & 425,65 \\
\hline Irish Stock Exchange & 394 & - & 3756 & - & - & - & - \\
\hline BME (spanish stock exchange) & 7794 & 1327 & 3696 & -6467 & 2369 & $-82,97$ & 178,52 \\
\hline Euronext & 11228 & 3455 & 3258 & -7773 & -197 & $-69,23$ & $-5,70$ \\
\hline Euronext Paris & 472 & 824 & 1976 & 352 & 1152 & 74,58 & 139,81 \\
\hline Euronext Amsterdam & 6113 & 2608 & 678 & -3505 & -1930 & $-57,34$ & $-74,00$ \\
\hline Euronext Brussels & 395 & 23 & 604 & -372 & 581 & $-94,18$ & 2526,09 \\
\hline
\end{tabular}




\begin{tabular}{|l|c|c|c|c|c|c|c|}
\hline Deutsche Börse stock Exchange & 6795 & 5022 & 2525 & -1773 & -2497 & $-26,09$ & $-49,72$ \\
\hline Börse Italy & 5265 & & & -5265 & 0 & $-100,00$ & - \\
\hline Warsaw & 440 & 262 & 1811 & -178 & 1549 & $-40,45$ & 591,22 \\
\hline Wiener Börse stock Exchange & & - & 168 & - & - & - & - \\
\hline Oslo Börs \& Oslo Axess Stock Exchange & 1078 & 287 & 1099 & -791 & 812 & $-73,38$ & 282,93 \\
\hline Borsa Istanbul & 42 & 103 & 278 & 61 & 175 & 145,24 & 169,90 \\
\hline Stock exchange Bucharest & & 51 & 256 & 51 & 205 & - & 401,96 \\
\hline Budapest & & 9 & 73 & 9 & 64 & - & 711,11 \\
\hline Prague stock Exchange & - & 656 & - & - & - & - & - \\
\hline Luxembourg & & 48 & - & 48 & - & - & - \\
\hline Sofia & 6 & 31 & - & 25 & - & 416,67 & - \\
\hline Zagreb & 36 & & & -36 & 0 & $-100,00$ & - \\
\hline Total & 57392 & 27888 & 43915 & -29504 & 16027 & $-51,41$ & 57,47 \\
\hline
\end{tabular}

Source: NASDAQ, IPO Watch Europe, 2017; IPO Watch Europe, 2018

Most European exchanges recorded a decline in 2015, however, the stock exchange Nasdaq Nordic became an exception, as the shares of companies listed on this exchange increased by $33 \%$ (NASDAQ).

In Table 3 the leading European companies in 2017 on the release of the initial placement of shares are shown.

Table 3. Leading European companies in 2017 on the issue of initial placement of shares

\begin{tabular}{|l|c|c|c|c|}
\hline \multicolumn{1}{|c|}{ Company } & millions euros & Industry & Stock exchange & Country \\
\hline Allied Irish Banks plc & 2,986 & Finances & $\begin{array}{c}\text { Irish stock exchange; } \\
\text { London stock exchan }\end{array}$ & Ireland \\
\hline Pirelli \& C SpA & 2,275 & Consumer goods & Borsa Italian & Italy \\
\hline Landis \& Gyr Holding AG & 2,08 & Industrial companies & Six swiss exchanges & Switzerland \\
\hline BAWAG Group AG & 1,68 & Finances & Wiener Börse & Australia \\
\hline Galenica Sante AG & 1,544 & Consumer services & Six swiss exchanges & Switzerland \\
\hline EN+ Group plc & 1,287 & Basic materials & London stock exchange & Russian federation \\
\hline ALD SA & 1,156 & Industrial companies & Euronext & France \\
\hline Play Communications SA & 1,041 & Telecommunications & Warsaw stock exchange & Poland \\
\hline J2 Acquisition Ltd & 1,029 & Finances & London stock exchange & United Kingdom \\
\hline Gestamp Automocion SA & 870 & Consumer goods & BME & Spain \\
\hline Total & 15,948 & & & \\
\hline
\end{tabular}

Source: EY Global, 2017

Investment companies, including SPACs and Real Estate Investments (REITs), accounted for 25\% of the UK's volumes and values in the IPO market. The annual profit from IPO is about 40 billion, and volumes grew by about $13 \%$, according to a recent analysis by PwC. The levels of foreclosed and delayed IPO (IPO) dropped almost twofold in 2017. The London Stock Exchange has become the most active market in Europe in 2017, with nearly $30 \%$ of revenue generated from European IPOs created in London.

In Table 4 the dynamics of the European market for IRO by sectors in 2015-2017 is shown. 
Table 4. Dynamics of the European market of IRO by sectors in 2015-2017

\begin{tabular}{|l|c|c|c|c|c|c|c|}
\hline \multirow{2}{*}{ Volume, million euros } & \multicolumn{3}{|c|}{ Years } & \multicolumn{2}{c|}{ Absolute deviation, +/- } & \multicolumn{2}{c|}{ Rate of increase, \% } \\
\cline { 2 - 8 } & 2015 & 2016 & 2017 & $2016-2015$ & $2017-2016$ & $2016 / 2015$ & $2017 / 2016$ \\
\hline Finances & 20500 & 7962 & 16719 & -12538 & 8757 & $-61,16 \%$ & $109,98 \%$ \\
\hline Industrial companies & 13162 & 4121 & 7887 & -9041 & 3766 & $-68,69 \%$ & $91,39 \%$ \\
\hline Consumer goods & 4017 & 1827 & 6428 & -2190 & 4601 & $-54,52 \%$ & $251,83 \%$ \\
\hline Consumer services & 6298 & 3517 & 4716 & -2781 & 1199 & $-44,16 \%$ & $34,09 \%$ \\
\hline Healthcare & 2971 & 2351 & 2115 & -620 & -236 & $-20,87 \%$ & $-10,04 \%$ \\
\hline Technology & 2969 & 309 & 2053 & -2660 & 1744 & $-89,59 \%$ & $564,40 \%$ \\
\hline Basic materials & 1546 & 33 & 1933 & -1513 & 1900 & $-97,87 \%$ & $5757,58 \%$ \\
\hline Telecommunications & 5441 & 438 & 1248 & -5003 & 810 & $-91,95 \%$ & $184,93 \%$ \\
\hline Utilities sector & 444 & 716 & 501 & 272 & -215 & $61,26 \%$ & $-30,03 \%$ \\
\hline Oil and gas & 44 & 170 & 315 & 126 & 145 & $286,36 \%$ & $85,29 \%$ \\
\hline Total & 57392 & 27888 & 43915 & -29504 & 16027 & $-51,41 \%$ & $57,47 \%$ \\
\hline
\end{tabular}

Source: IPO Watch Europe, 2017; IPO Watch Europe, 2018

Therefore, it may be noted that the Irish company placed the largest share in the European IPO market in 2017. Exit companies to the European IPO market increased by 50\% in 2017 compared to 2016. The London Stock Exchange has become the most active market in Europe, where revenues from IPO increased by about $75 \%$ higher than in 2016.

The financial sector remains the largest IPO sector, despite a significant decline in 2015, due to the elimination of shares by Nets and ASR Nederland. The utilities sector recovered after 2015, after the mega IPO of NGO and Dong Energy (EY Global, 2017).

Studies have shown that the global market of IRO, the emergence of which dates from the beginning of the seventeenth century, has repeatedly changed the vector of its development due to certain historical events. However, its most significant achievements occurred only at the present stage of development of the world economy as a result of the expansion of integration and globalization processes, which had a significant impact on the functioning of international capital markets. The possibility of IPO operations in the world market is conditioned by: a) the internationalization of national markets and the formation of the world capital market; b) its steady growth irrespective of the dynamics of the development of the world economy; c) the increase of financial challenges caused by the high degree of uncertainty of the development of national markets, which increases the probability of a negative impact of one economy on another (Oyegoke, 2012). The analysis of the current state and trends of the world market of IPO has allowed to distinguish such key trends of its development:

- there is a slight increase in the number and volume of IPOs, with the exception of the temporary fall of markets due to global crises;

- impact on the activity of the market of IPO on the growth (fall) of the economy due to global economic crises;

- Another variability of leadership positions in the markets of IPOs of the leading countries of the world. The main role in this process is played by the Chinese issuers who are undergoing the process of privatization, and the American financial corporations that are trying to solve their problems through the attraction of capital in the open market.

In the context of globalization, important factors in the development of companies in different countries of the world are also foreign investments that are rotated in the international capital market, and in particular in the public offering market (IPO). Despite the current investment situation, the overall dynamics of the IPO market is growing, attracting funds through the IRO is increasingly becoming a source of financing for the development of companies. Therefore, the study of this means of attracting foreign investment is of interest to many companies that plan to improve their investment attractiveness. 


\section{Ukrainian IPO market}

The IPO market has started it's fully functioning in Ukraine since 2005. The history of the IPO in Ukraine counts over 13 years since the first Ukrainian placement held on February 11, 2005 at the Alternative Stock Exchange of the London Stock Exchange (AIM LSE; Information Agency UNIAN).

In its development, the IPO market, like any other financial market, is exposed to world market conditions (IPO / SPO v Ukraine). Over the past 15 years, with the world's largest market IPO was achieved in 2007, when, according to the audit company EY, the amount of attracted capital companies around the world amounted to $\$ 338$ billion. In the same year, a record number of placements - almost 2 thousand ( State Statistics Service of Ukraine, 2018). It is during the phase of world market growth in 2005-2007 (National Securities and Stock Market Commission, 2018). The IPO was held by Ukrainian agroholdings Ukrproduct, Astarta, Landkom and Kernel. The fall of the IPO market led to the fact that in 2008 only one Ukrainian agro company - MHP conducted an IPO. In 2009, there were no placement of securities of agricultural corporations from Ukraine (Resolution of the Board of the National Bank of Ukraine, 2015, State Statistics Service of Ukraine, 2018).

In Table 5 the IPO volume of Ukrainian companies in 2007-2017 is shown.

Table 5. Volumes of major IPO of Ukrainian companies in 2007-2017

\begin{tabular}{|c|c|c|c|c|}
\hline $\begin{array}{l}\text { The name of the company } \\
\text { that made the IPO / SPO }\end{array}$ & Industry & Stock exchange & \begin{tabular}{|c|} 
Amount of \\
attracted funds, \\
million USD \\
\end{tabular} & $\begin{array}{l}\text { End/placement } \\
\text { date }\end{array}$ \\
\hline Ferrexpo & Metallurgy and Mining & $\mathrm{L}$ & 449 & 20.06 .2007 \\
\hline Nostra Terra & Oil and gas & LSE's AIM & 72 & 20.07 .2007 \\
\hline Landkom & Agriculture and agroindustrial complex & LSE's AIM & 110 & 22.11 .2007 \\
\hline Kernel Holding & $\begin{array}{l}\text { Food, Agriculture and agroindustrial } \\
\text { complex }\end{array}$ & Warsaw & 220 & 23.11.2007 \\
\hline Kernel Holding / SPO-1 & $\begin{array}{l}\text { Food, Agriculture and agroindustrial } \\
\text { complex }\end{array}$ & Warsaw & 84 & 12.03.2008 \\
\hline Cadogan Petroleum & Oil and gas & $\mathrm{L}$ & 302 & 23.06 .2008 \\
\hline Kernel Holding / SPO-2 & $\begin{array}{l}\text { Food, Agriculture and agroindustrial } \\
\text { complex }\end{array}$ & Warsaw & 81 & 05.05 .2010 \\
\hline $\begin{array}{l}\text { AVANGUARD } \\
\text { AGROHOLDING }\end{array}$ & Agriculture and agroindustrial complex & $\mathrm{L}$ & 188 & 06.05 .2010 \\
\hline $\begin{array}{l}\text { Russian navigational } \\
\text { technologies }\end{array}$ & $\begin{array}{l}\text { Technologies, telecommunications and } \\
\text { media }\end{array}$ & ММВБ & 10 & 07.07 .2010 \\
\hline Agroliga & Agriculture and agroindustrial complex & Warsaw & 1 & 30.09 .2010 \\
\hline Agroton & Agriculture and agroindustrial complex & Warsaw & 54 & 29.10 .2010 \\
\hline Milkiland & Food industry & Warsaw & 79 & 26.11 .2010 \\
\hline Geo-Alliance & Oil and gas & Warsaw & 255 & 08.12 .2010 \\
\hline Sadovaya Group & coal & Warsaw & 31 & 21.12 .2010 \\
\hline Black Iron & Metallurgy and Mining & Toronto & 36 & 29.03 .2011 \\
\hline Kernel Holding & Agriculture and agroindustrial complex & Warsaw & 140 & 01.04 .2011 \\
\hline KSG Agro & Agriculture and agroindustrial complex & Warsaw & 44 & 15.04 .2011 \\
\hline Industrial dairy company & Agriculture and agroindustrial complex & Warsaw & 30 & 21.04 .2011 \\
\hline Yandex & $\begin{array}{l}\text { Technologies, telecommunications and } \\
\text { media }\end{array}$ & NASDAQ & 1435 & 23.05 .2011 \\
\hline Westa ISIC S.A. & other industries & Warsaw & 48 & 06.06 .2011 \\
\hline Ovostar Union N.V. & Agriculture and agroindustrial complex & Warsaw & 33 & 20.06 .2011 \\
\hline Continental Farmers Group & Agriculture and agroindustrial complex & London & 24 & 28.06 .2011 \\
\hline ViOil Holding S.A. & Agriculture and agroindustrial complex & Warsaw & 150 & 06.07 .2011 \\
\hline Coal Energy & coal & Warsaw & 80 & 15.07 .2011 \\
\hline AgroGeneration (SPO) & Agriculture and agroindustrial complex & NYSE & 16 & 21.07 .2011 \\
\hline
\end{tabular}




\begin{tabular}{|c|c|c|c|c|}
\hline $\begin{array}{c}\text { TMM Real Estate } \\
\text { Development (SPO) }\end{array}$ & Real estate and development & London, Warsaw & 100 & 13.01 .2012 \\
\hline EPAM SYSTEMS & $\begin{array}{c}\text { Technologies, telecommunications and } \\
\text { media }\end{array}$ & NYSE & 72 & 08.02 .2012 \\
\hline Arricano Real Estate PLC & Real estate and development & LSE's AIM & 24 & 12.09 .2015 \\
\hline Interfom & Chemical industry & Warsaw & 26 & 2016 \\
\hline Ukrgazvydobuvannya & Oil and gas & Warsaw & 1200 & 2016 \\
\hline MCB Agricole & Agriculture & Warsaw & 25 & 2017 \\
\hline Ukrzernoprom & Oil and gas & Warsaw & 33 & 2017 \\
\hline
\end{tabular}

Source: The First Stock Trading System, 2017; National Securities and stock market commission, 2018; The Ukrainian representative WSE; The Warsaw Stock Exchange

In Figure 2 reflects the dynamics of the IPO market in Ukraine in 2007-2017.

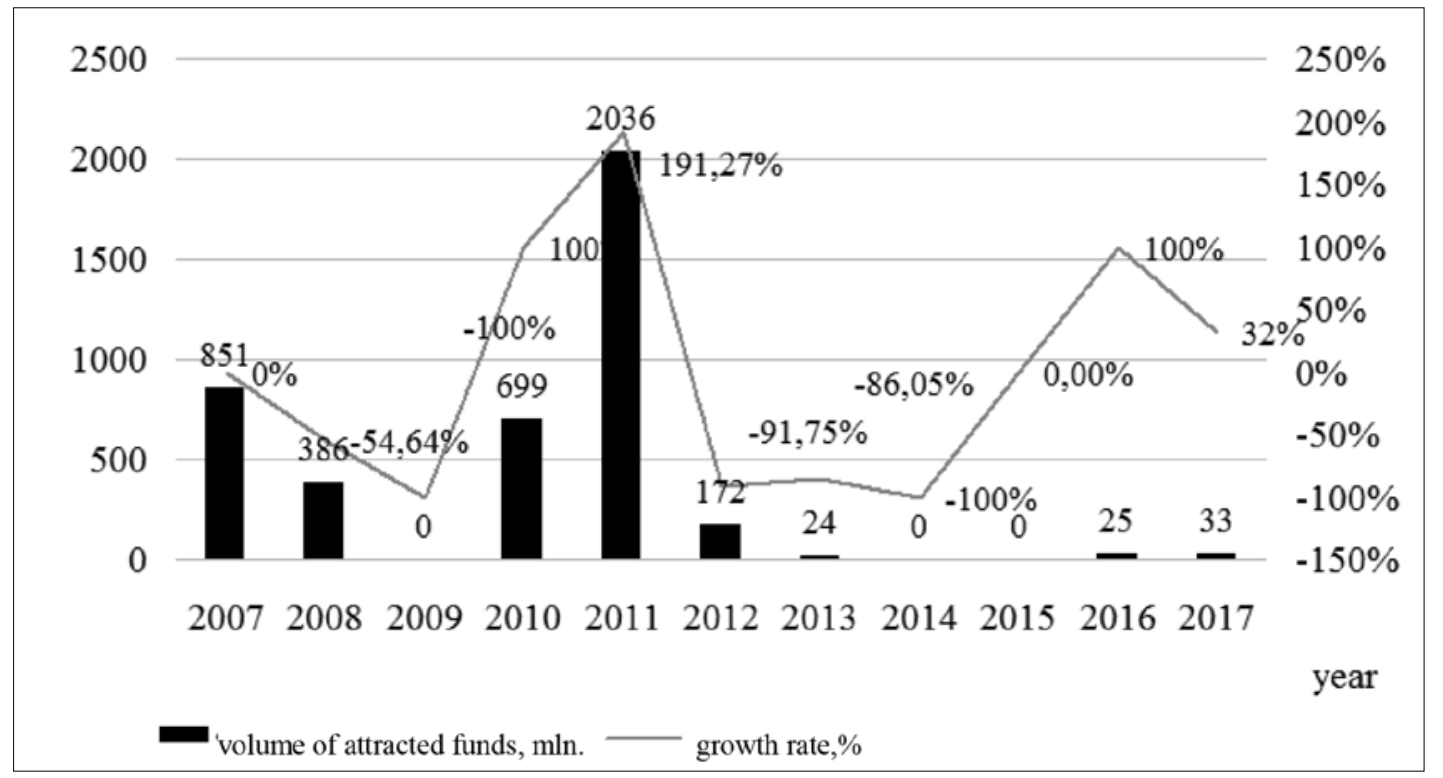

Figure 2. Dynamics of the IPO market in Ukraine in 2007-2017

Source: Prepared by the authors from statistical processing results

In order to study the influence of indicators of IRO on the parameters of macroeconomic security, we used a correlation-regression analysis to determine the pair effect (Figure 3).
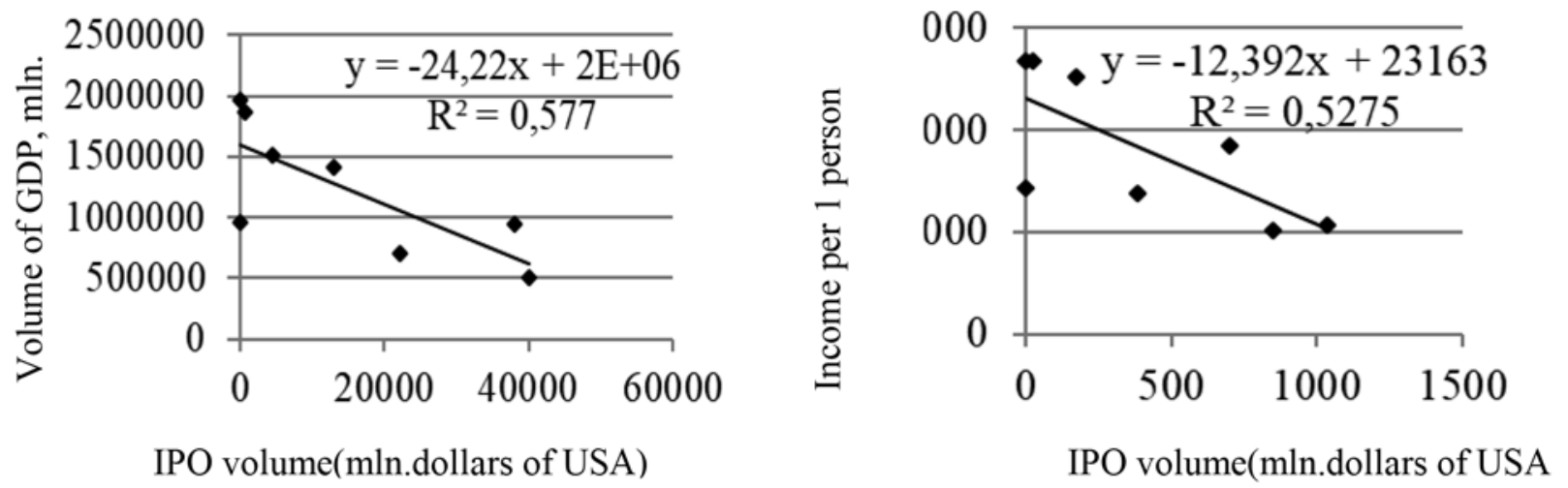

Figure 3. Dependence of macroeconomic security parameters on volumes of IRO Source: Prepared by the authors from the statistical processing results 
According to the calculations we can conclude that the determination coefficient $\mathrm{R} 2=0,58$ means that $58 \%$ of the variation in the volume of IPO (Y) is due to the variation of factor X - the volume of GDP, and 42\% - by influence of other factors not included in the model. The determination coefficient R2 $=0.53$ means that $53 \%$ of the variation in the volume of the IPO (Y) is due to the variation of factor $\mathrm{X}$ - the disposable income per capita and $47 \%$ the effects of other factors not included in the model. The determination coefficient $\mathrm{R} 2=0.51$ means that $51 \%$ of the variation in the volume of the IPO $(\mathrm{Y})$ is due to the variation of the factor $\mathrm{X}$ - the unemployment rate, and $49 \%$ - by the actions of other factors not included in the model. The determination coefficient $\mathrm{R} 2=$ 0.51 means that $51 \%$ variation in the volume of IPO (Y) is due to the variation of factor $\mathrm{X}$ - trade balance, and $49 \%$ due to other factors not included in the model (National Rating Agency "Rurik", 2018). The closest connection and the greatest impact on the volume of IRO is the volume of GDP.

\section{Conclusions}

One of the major problems is the dependence of the IPO market on the growth rate of the economy, as during the financial crises the production of IPO is significantly reduced. The main content of economic growth is to increase the country's economic potential and its macroeconomic security, the capacity of its economy, that is, to increase its real GDP. In addition, the level of economic security of the country is measured by the level of unemployment, disposable income per capita, trade balance and other indicators.

There is an increase of IPO at the European IPO market at the period of 2016-2017. In 2017, the number of companies in the European market increased by 50\%, compared with 2016. The London Stock Exchange has become the most active market in Europe, where IPO revenues have increased by about $75 \%$ higher than in 2016. The largest share in the IPO market is in the financial sector by IPO. While the world IPO (IPO) market is gradually recovering and shows growth trends, the Ukrainian IPO market is characterized by low awareness of companies and their ability to place shares in order to attract investment resources. During the period of 20082014 Ukrainian companies implemented 59 IPO (IPO) placements, attracted \$ 6.2 billion, representing 0.9\% of global volumes by number of placements and $0.6 \%$ of funds raised, but the average the size of transactions is 105 billion dollars. USA.

According to the results of the correlation-regression analysis, it was established that the decline of the IRO was influenced by the economic downturn in Ukraine, reflected in the growth of unemployment, the reduction of GDP, the negative trade balance, the reduction of disposable income per capita, etc., which indicates a direct dependence between volumes of IRO on the parameters of macroeconomic safety.

\section{References}

Afza, T.; Yousaf, H. and Alam, A. (2013). Information asymmetry, corporate governance and IPO under-pricing. Science International, 25(4): 989-997.

Ashraf, M.; Masood, O.; Tvaronavičienė, M.; Aktan, B.; Garškaitė-Milvydienė, K.; Lace, N. (2019). Factors Affecting Development Patterns: Econometric Investigation of Japan Equity Market. Economic Research-Ekonomska Istraživanja, 32(1): 440-453, https://doi. org/10.1080/1331677X.2018.1551147

Bochner, Steven E.; Avina, Jon C.; Cheng, Calise Y. (2016). Guide to the initial public offering. Minnesota: St. Paul, Published by Merrill Corporation URL: https://www.wsgr.com/publications/PDFSearch/IPOGuide2016.pdf

Boulton, T.J.; Smart, S.B.; Zutter, C.J. (2009). IPO underpricing and international corporate governance. Journal of International Business Studies, 41(2): 206-222.

Bruton, G.D.; Filatotchev, I.; Chahine, S. and Wright, M. (2009). Governance, ownership structure, and performance of IPO firms: the impact of different types of private equity investors and institutional environments. Strategic Management Journal, 31(5): 491-509. https://doi.org/10.1002/smj.822

Consulting firm (Poland) [Online]. Available on the Internet: progressholding.pl. URL: https://www.atkearney.pl/

Elston, J.A.; Yang, J.J. (2010). Venture capital, ownership structure, accounting standards and IPO underpricing: evidence from 
Germany. Journal of Economics and Business, 62(6): 517-536. https://doi.org/10.1016/j.jeconbus.2010.08.003

Engelen, P.J.; Essen, M.V. (2010). Underpricing of IPOs: firm-, issue- and country-specific characteristics. Journal of Banking \& Finance, 34(8): 1958-1969. https://doi.org/10.1016/j.jbankfin.2010.01.002

EY Global. (2017). Reading allowed: Global IPO trends Q3 (2017). Retrieved from: http://www.ey.com/Publication/ vwLUAssets/eyglobal-ipo-trends-q3-2017/\$FILE/ey-global-ipo-trends-q3-2017.pdf

Gajewski, J.F.; Gresse, C. (2006). A Survey of the European IPO Market, ECMI. Available on the Internet: http://www.eurocapitalmarkets. org

Drobyazko S. (2018a) Personnel management as element of the economic safety system of business. Rocznik Aaministracji Publicznej, (4): 210-218. https://doi.org/10.4467/24497800RAP.18.012.9227

Drobyazko S. (2018b) Formation of competitive positions as providing of economic security of insurance companies. International scientific journal “Internauka”. Series: "Economic Sciences”. 2017. №2. https://doi.org/10.25313/2520-2294-2017-2-4784

Hoechle, D.; Schmid, M. (2007). Which, Why, and for How Long do IPOs Underperforms? Working paper. URL: https://pdfs. semanticscholar.org/07a0/01cbfe92930e48cbb39cf18bc18cf9ffec0a.pdf

Initial Public Offerings, Pricing Differences. Available on the Internet: https://www.sec.gov/fast-answers/answersipopricinghtm.html

Information Agency UNIAN [Online]. Available on the Internet: https://www.economics.unian.net

Investor Alert: Pre-IPO Investment Scams (Updated). Available on the Internet: https://www.investor.gov/additional-resources/newsalerts/alerts-bulletins/investor-alert-pre-ipo-investment-scams-updated

IPO / SPO v Ukraine. Available on the Internet: http://www.preqveca.ru/placements/?sf $\% 5 B i p o \_t \% 5 \mathrm{D}=\& \mathrm{sf} \% 5 \mathrm{Bipo} \% 5 \mathrm{D}=0 \& \mathrm{sf} \% 5 \mathrm{~B}$ status $\% 5 \mathrm{D}=0 \& \mathrm{sf} \% 5 \mathrm{~B}$ countr $\% 5 \mathrm{D}=3 \& \mathrm{sf} \% 5 \mathrm{Bspec} \% 5 \mathrm{D}=0 \& \mathrm{sf} \% 5 \mathrm{Blisting} \% 5 \mathrm{D}=0 \& \mathrm{sf} \% 5 \mathrm{Bpsf} \% 5 \mathrm{D}=01.01 .2007 \& \mathrm{sf} \% 5 \mathrm{Bpst} \% 5 \mathrm{D}=31-$ $.12 .2017 \& \mathrm{sf} \% 5 \mathrm{Bpt} \% 5 \mathrm{D}=0 \& \mathrm{sf} \% 5 \mathrm{Bind} \% 5 \mathrm{D}=0 \& \mathrm{sf} \% 5 \mathrm{Bpef} \% 5 \mathrm{D}=\& \mathrm{sf} \% 5 \mathrm{Bpet} \% 5 \mathrm{D}=\#$ search $\mathrm{r}$

IPO Watch Europe (2017). PricewaterhouseCoopers LLP Outlook. Available on the Internet: https://www.pwc.co.uk/audit-assurance/ assets/pdf/ipo-watch-europe-2017.pdf

IPO Watch Europe (2018). PricewaterhouseCoopers LLP Outlook. Available on the Internet: https://www.pwc.co.uk/audit-assurance/ assets/pdf/ipo-watch-europe-annual-review-2018.pdf

Karpenko, L.; Serbov, M.; Kwilinski, A.; Makedon, V. \& Drobyazko, S. (2018). Methodological platform of the control mechanism with the energy saving technologies, Academy of Strategic Management Journal, 17(5) URL: https://www.abacademies.org/articles/ Methodological-platform-of-the-control-mechanism-1939-6104-17-5-271.pdf

Korauš, A.; Gombár, M.; Kelemen, P.; Backa, S. (2019). Using quantitative methods to identify insecurity due to unusual business operations. Entrepreneurship and Sustainability Issues, 6(3): 1101-1012. http://doi.org/10.9770/jesi.2019.6.3(3)

Johnston, J.; Madura, J. (2009). The pricing of IPOs post-Sarbanes-Oxley. The Financial Review, 44(2): 291-310. https://dx.doi. org/10.1111/j.1540-6288.2009.00219.x

Lin, C.P.; Chuang, C.M. (2011). Principal-principal conflicts and IPO pricing in an emerging economy. Corporate Governance: An International Review, 19(6): 585-600. URL: https://www.napier.ac.uk/ /media/worktribe/output-970196/an-empirical-examination-ofipo-underpricing-between-high-technology.pdf

Loughran, T.; Ritter, J. (2004). Why has IPO underpricing increased over time. Financial Management, 33(3): 5-37. URL: https://site. warrington.ufl.edu/ritter/files/2016/06/why-has-IPO-Underpricing-Increased-Over-Time.pdf

Makedon V.; Korneyev M. (2014). Improving methodology of estimating value of financial sector entities dealing in mergers and acquisitions. Investment Management and Financial Innovations, 11(1): 44-55.

Mangena, M.; Pike, R. (2005). The effect of audit committee shareholding, financial expertise and size on interim financial disclosures. Accounting and Business Research, 35(4): 327-349. https://doi.org/10.1080/00014788.2005.9729998

Masood, O.; Aktan, B.; Gavurová, B.; Fakhry, B.; Tvaronavičienė, M., Martinkutė-Kaulienè, R. (2017). The impact of regime-switching behaviour of price volatility on efficiency of the US sovereign debt market. Economic Research-Ekonomska Istraživanja, 30:1, 1865$1881 \mathrm{http}: / /$ dx.doi.org/10.1080/1331677X.2017.1394896

Masood, O.; Tvaronavičienė, M.; Javaria, K. (2019). Impact of oil prices on stock return: evidence from G7 countries. Insights into 
JOURNAL OF SECURITY AND SUSTAINABILITY ISSUES

ISSN 2029-7017 print/ISSN 2029-7025 online

Regional Development, 1(2): 129-137. https://doi.org/10.9770/ird.2019.1.2(4)

Mokhova, N., Zinecker, M., Meluzín, T. (2018). Internal factors influencing the cost of equity capital, Entrepreneurship and Sustainability Issues 5(4): 827-845. http://doi.org/10.9770/jesi.2018.5.4(9)

NASDAQ [Online]. Available on the Internet: http://www.nasdaq.com

National Rating Agency «Rurik» (2018). Available on the Internet: http://rurik.com.ua/

State Statistics Service of Ukraine (2018). Available on the Internet: http://www.ukrstat.gov.ua/

The First Stock Trading System (2017). Available on the Internet: http://www.pfts.ua/

National Securities and stock market commission (2018). Available on the Internet: http://www.nssmc.gov.ua/

Oyegoke, A.S. (2012). Transparency in public procurement: a study of the European Union directive for public works, supply and services contracts. International Journal of Business Excellence, 5(3): 195-219. https://dx.doi.org/10.1504/IJBEX.2012.046639

Poberezhets O.; Kovalova O.; Iorgachova M. (2018). Transformation processes of the ipo market: Ukrainian and world experience. Baltic Journal of Economic Studies, 4(2): 178-183. https://doi.org/10.30525/2256-0742/2018-4-2-178-183

Resolution of the Board of the National Bank of Ukraine (2015). Reading allowed: Complex program of development of the financial sector of Ukraine till 2020. Retrieved from: https://bank.gov.ua/doccatalog/document?id=18563297

Shuyan, L.; Fabuš, M. 2019. Study on the spatial distribution of China's Outward Foreign Direct Investment in EU and its influencing factors. Entrepreneurship and Sustainability Issues, 6(3):1080-1096. http://doi.org/10.9770/jesi.2019.6.3(16)

State Statistics Service of Ukraine (2018). Available on the Internet: http://www.ukrstat.gov.ua/

Ritter, J.R. (2011). Equilibrium in the IPO Market, Working Paper [Online]. Available on the Internet: http://ssrn.com

Štiglic, D. (2017). Towards security through economic policy: a Baldwin's approach, Journal of Security and Sustainability Issues 7(1): 55-65. https://doi.org/10.9770/jssi.2017.7.1(6)

The Ukrainian representative WSE [Online]. Available on the Internet: www.ipowse.com.ua

The Warsaw Stock Exchange [Online]. Available on the Internet: www.gpw.pl

Tvaronavičienė, M. (2018). Toward efficient policy making: forecasts of vulnerability to external global threats. Journal of Security and Sustainability Issues, 7(3): 591-600. https://doi.org/10.9770/jssi.2018.7.3(18)

Welch, I. and Ritter, J. (2002). A Review of IPO Activity, Pricing and Allocations. Working paper, No. 02-01, Yale University. https:// doi.org/10.1111/1540-6261.00478 
Short biographical note about the contributors at the end of the article:

Marek GARBOWSKI, PhD in economics, Assistant Professor, University of Warmia and Mazury in Olsztyn, Poland

ORCID ID: orcid.org/0000-0003-2415-2597

Daria MIRONOVA, PhD in economics, Assistant Professor, Institute of Service and Business (branch) of Don State Technical University

ORCID ID: orcid.org/0000-0002-2909-2442

Iryna PEREVOzOVA, Doctor of Economics, Professor, Head of the Department of Entrepreneurship and Marketing, IvanoFrankivsk National Technical University of Oil and Gas

ORCID ID: orcid.org/0000-0002-3878-802X

Nila KHRUSHCH, Doctor of Economics, Professor, Head of Department of Finance, Banking and Insurance, Khmelnytskyi National University

ORCID: ID: orcid.org/0000-0002-9930-7023

Iurii GUDZ, Ph.D. (Economics), Associate Professor, Donetsk National University of Economics and Trade named after Mykhailo Tugan-Baranovsky

ORCID ID: https://0000-0003-4150-7425

Register for an ORCID ID:

https://orcid.org/register

This work is licensed under the Creative Commons Attribution International License (CC BY). http://creativecommons.org/licenses/by/4.0/ 